\title{
Liver fibrosis progression in HIV/hepatitis C virus coinfected patients with normal aminotransferases levels
}

\author{
Progressão da fibrose hepática em portadores de coinfecção HIV/vírus da hepatite C com \\ níveis de aminotransferases normais
}

\author{
Fábio Heleno de Lima Pace ${ }^{1}$, Lincoln Eduardo Vieira de Castro Ferreira ${ }^{2}$, Antonio Eduardo Benedito Silva ${ }^{3}$ \\ and Maria Lucia Gomes Ferraz ${ }^{3}$
}

\section{ABSTRACT}

Introduction: Approximately $30 \%$ of hepatitis C virus (HCV) monoinfected patients present persistently normal alanine aminotransferase (ALT) levels. Most of these patients have a slow progression of liver fibrosis. Studies have demonstrated the rate of liver fibrosis progression in hepatitis $\mathrm{C}$ virus-human immunodeficiency virus (HCV-HIV) coinfected patients is faster than in patients infected only by HCV. Few studies have evaluated the histological features of chronic hepatitis C in HIV-infected patients with normal ALT levels. Methods: HCV-HIV coinfected patients (HCV-RNA and anti-HIV positive) with known time of HCV infection (intravenous drugs users) were selected. Patients with hepatitis B surface antigen (HBsAg) positive or hepatitis $\mathrm{C}$ treatment before liver biopsy were excluded. Patients were considered to have a normal ALT levels if they had at least 3 normal determinations in the previous 6 months prior to liver biopsy. All patients were submitted to liver biopsy and METAVIR scale was used. Results: Of 50 studied patients 40 (80\%) were males. All patients were treated with antiretroviral therapy. The ALT levels were normal in $13(26 \%)$ patients. HCV-HIV co-infected patients with normal ALT levels had presented means of the liver fibrosis stages $(0.77 \pm 0.44$ versus $1.86 \pm 1.38 ; \mathrm{p}<0.001)$ periportal inflammatory activity $(0.62 \pm 0.77$ versus $2.24 \pm 1.35 ; \mathrm{p}<0.001)$ and liver fibrosis progression rate $(0.058 \pm 0.043$ fibrosis unit/year versus $0.118 \pm 0.102$ fibrosis unit/year) significantly lower as compared to those with elevated ALT. Conclusions: HCV-HIV coinfected patients with persistently normal ALTs showed slower progression of liver fibrosis. In these patients the development of liver cirrhosis is improbable. Keywords: Liver cirrhosis. Hepatitis C. HIV. Aminotransferase.

\section{RESUMO}

Introdução: Aproximadamente, 30\% dos portadores de hepatite crônica C apresentam níveis de aminotransferases persistentemente normais (APNL). A maioria destes pacientes tem lenta progressão da fibrose hepática. Em portadores de coinfecção VHC-HIV, estudos têm demonstrado que a progressão da fibrose hepática é mais rápida que a observada em indivíduos infectados somente pelo VHC. Há poucos estudos que verificaram as características histológicas da hepatite crônica $\mathrm{C}$ em pacientes coinfectados pelo HIV APNL. Métodos: Portadores de coinfecção VHC-HIV (HCV-RNA e anti-HIV positivos) com tempo de infecção pelo VHC conhecido (uso de drogas intravenosas) foram selecionados. Aqueles com hepatitis B surface antigen $(\mathrm{HbsAg}$ ) positivo ou que tenham sido submetidos à terapia antiviral para hepatite $\mathrm{C}$ antes da biópsia hepática foram excluídos. Pacientes com pelo menos 3 determinações normais da ALT nos últimos 6 meses antes da biópsia hepática foram considerados como tendo APNL. Todos foram submetidos a biópsia hepática que foi classificada de acordo com a escala METAVIR. Resultados: Foram incluídos 50 pacientes, 40 (80\%) homens. Todos receberam terapia antirretroviral. Os níveis de ALT foram persistentemente normais em 13 (26\%) pacientes. Pacientes coinfectados com APNL apresentaram menor média dos estágiosde fibrose hepática $(0,77 \pm 0,44$ versus $1,86 \pm 1,38 ; \mathrm{p}<0,001)$, dos índices de atividade inflamatória periportal $(0,62 \pm 0,77$ versus $2,24 \pm 1,35 ; \mathrm{p}<0,001)$ e progressão mais lenta da fibrose hepática $(0,058 \pm 0,043$ unidades de fibrose /ano versus $0,118 \pm 0,102$ unidades de fibrose/ano) quando comparados àqueles com aminotransferases elevadas. Conclusões: Portadores de coinfecção VHC-HIV com APNL apresentam progressão mais lenta da fibrose hepática. Nesses pacientes o desenvolvimento de cirrose hepática é improvável.

Palavras-chaves: Cirrose hepática. Hepatite C. HIV. Aminotransferases.

1. Departamento de Gastroenterologia, Centro de Referência em Hepatologia, Universidade Federal de Juiz de Fora, Juiz de Fora, MG. 2. Unidade de Endoscopia Digestiva, Universidade Federal de Juiz de Fora, Juiz de Fora, MG. 3. Seção de Hepatites, Divisão de Gastroenterologia, Universidade Federal de São Paulo, São Paulo, SP.

Address to: Dr. Fábio Heleno de Lima Pace. R. Professor Ivan Dias Raimundo 20, Spina Ville II, 36036-785 Juiz de Fora, MG, Brasil.

Phone/Fax: 5532 4009-5302

e-mail: fpace@oi.com.br

Received in $26 / 10 / 2011$

Accepted in 13/02/2012

\section{INTRODUCTION}

Due to shared risk factors for transmission of coinfection with human immunodeficiency virus (HIV) and hepatitis $\mathrm{C}$ virus (HCV) it is a very common event. It is estimated that around $30 \%$ of $\mathrm{HIV}$-infected patients are coinfected with $\mathrm{HCV}$ in the United States and Europe ${ }^{1-7}$. The mode of HIV acquisition is directly associated with prevalence rates of $\mathrm{HCV}$ co-infection. Thus, the prevalence of HCV among men who have sex with men is approximately $10 \%$, while $70-90 \%$ of the intravenous drugs users (IDU) are HCV co-infected ${ }^{1,8,9}$.

Liver disease caused by HCV is now the leading cause of morbidity and mortality among HIVinfected patients in the developed world where classic severe immunodeficiency opportunistic infections have considerably declined as a result of the widespread use of potent antiretroviral therapy ${ }^{10-15}$.

Several studies have demonstrated the deleterious HIV immunodeficiency action on the natural history of chronic hepatitis $\mathrm{C}$. The rate of liver fibrosis progression in HCV-HIV coinfected patients is about 1.5 to 2 times faster than in patients infected only by $\mathrm{HCV}^{16-20}$. However, most of the studies were carried out during the pre-highly active antiretroviral therapy (HAART) era and only HCV-HIV coinfected patients with elevated aminotransferases levels were included, which may have overestimated the severity of the HCV induced liver disease.

The real effect of HAART on the natural history of chronic hepatitis $\mathrm{C}$ in HIV infected patients is still unclear. Two studies reported that HCV-HIV coinfected patients submitted to HAART based on the use of protease inhibitors presented slower liver fibrosis progression ${ }^{21,22}$. Another study published by Qurish et al. found that HAART reduced liver related mortality in HCV-HIV coinfected patients ${ }^{23}$. On the other hand, Zylberberg et al described that the immunologic reconstitution after HAART 
accelerated progression of chronic hepatitis $\mathrm{C}$ to more advanced liver fibrosis stages ${ }^{24}$ and Antonello et al reported that coinfected patients showed a higher aspartate aminotransferase to platelet ratio index (APRI), a noninvasive liver fibrosis marker, after six months of HAART when compared with hepatitis $\mathrm{C}$ monoinfected patients ${ }^{25}$.

Approximately $30 \%$ of chronic hepatitis C carriers present persistently normal alanine aminotransferase (ALT) levels. Most of these patients show mild histological lesions and have slow liver fibrosis progression ${ }^{26,27}$. Prospective studies and outcome modeling projections suggest that the risk of liver disease progression towards severe fibrosis/cirrhosis is minimal at $10-15$ years in hepatitis $C$ virus carriers with persistently normal $\mathrm{ALT}^{28}$.

In the world, few studies have evaluated the behavior of chronic hepatitis $\mathrm{C}$ in HIV-infected patients with normal aminotransferases levels ${ }^{29-31}$. In HCV-HIV coinfected Brazilian patients, the prevalence of individuals with normal aminotransferases levels, the rate of liver fibrosis progression and their histological characteristics, remain to be studied.

\section{METHODS}

From June 2001 to June 2004, there were, HCV-HIV coinfected patients followed in Federal University of São Paulo, Brazil, based on serum antibody detection with a third generation enzymelinked immunosorbent assay. Serum HCV-RNA was detected by qualitative polimerase chain reaction (PCR-Amplicor; Roche Diagnostic Systems). Only patients with known HCV infection duration were selected. The HCV infection onset was considered as the first year of intravenous drugs usage, or transfusion. Exclusion criteria: presence of hepatitis B surface antigen (HBsAg) or hepatitis $\mathrm{C}$ treatment before liver biopsy. Patients were considered to have

TABLE 1 - Comparative analysis of clinical characteristics between patients with normal and altered aminotransferases levels $(\mathbf{n}=\mathbf{5 0})$.

\begin{tabular}{|c|c|c|c|c|c|c|c|}
\hline \multirow[b]{2}{*}{ Variables } & \multicolumn{2}{|c|}{$\begin{array}{c}\text { All } \\
(\mathbf{n}=\mathbf{5 0})\end{array}$} & \multicolumn{2}{|c|}{$\begin{array}{c}\text { Normal ALT } \\
\quad(n=13) \\
\end{array}$} & \multicolumn{2}{|c|}{$\begin{array}{l}\text { Altered ALT } \\
\quad(\mathbf{n}=\mathbf{3 7})\end{array}$} & \multirow[b]{2}{*}{$\mathbf{P}$} \\
\hline & $\mathbf{n}$ & $\%$ & $\mathbf{n}$ & $\%$ & $\mathbf{n}$ & $\%$ & \\
\hline Men & 40 & 80.0 & 11 & 85.0 & 29 & 78.0 & NS \\
\hline Age at biopsy - years (mean \pm SD) & \multicolumn{2}{|c|}{$38.5 \pm 6.6$} & \multicolumn{2}{|c|}{$38 \pm 7.8$} & \multicolumn{2}{|c|}{$39 \pm 6.2$} & NS \\
\hline Age at $\mathrm{HCV}$ infection - years $($ mean $\pm \mathrm{SD})$ & \multicolumn{2}{|c|}{$21.5 \pm 7.9$} & \multicolumn{2}{|c|}{$22 \pm 8.4$} & \multicolumn{2}{|c|}{$21 \pm 7.8$} & NS \\
\hline $\mathrm{HCV}$ infection duration - years $($ mean $\pm \mathrm{SD})$ & \multicolumn{2}{|c|}{$17.1 \pm 5.5$} & \multicolumn{2}{|c|}{$16 \pm 5.5$} & \multicolumn{2}{|c|}{$17 \pm 5.5$} & NS \\
\hline Alcohol consumption $>50 \mathrm{~g} /$ day & 25 & 50.0 & 6 & 46.0 & 19 & 51.0 & NS \\
\hline Drug intravenous user & 43 & 86.0 & 10 & 77.0 & 33 & 89.0 & NS \\
\hline HAART & 41 & 82.0 & 11 & 85.0 & 30 & 81.0 & NS \\
\hline PI use & 23 & 46.0 & 6 & 46.0 & 17 & 46.0 & NS \\
\hline
\end{tabular}

ALT: alanine aminotransferase; SD: standard deviation; HCV: hepatitis C virus; HAART: highly active anti-retroviral therapy; PI: protease inhibitor; NS: not significant.

TABLE 2 - Comparative analysis of biological parameters between patients with normal and altered aminotransferases levels $(\mathbf{n}=\mathbf{5 0})$.

\begin{tabular}{|c|c|c|c|c|c|c|c|}
\hline \multirow[b]{2}{*}{ Variables } & \multicolumn{2}{|c|}{$\begin{array}{c}\text { All } \\
(\mathbf{n}=\mathbf{5 0})\end{array}$} & \multicolumn{2}{|c|}{$\begin{array}{c}\text { Normal ALT } \\
(\mathbf{n}=13)\end{array}$} & \multicolumn{2}{|c|}{$\begin{array}{c}\text { Altered ALT } \\
\quad(\mathbf{n}=\mathbf{3 7})\end{array}$} & \multirow[b]{2}{*}{$\mathbf{P}$} \\
\hline & $\mathbf{n}$ & $\%$ & $\mathbf{n}$ & $\%$ & $\mathbf{n}$ & $\%$ & \\
\hline $\mathrm{CD} 4$ count - cells $/ \mathrm{mm}^{3}$ (mean $\left.\pm \mathrm{SD}\right)$ & \multicolumn{2}{|c|}{$424.3 \pm 234.4$} & \multicolumn{2}{|c|}{$472 \pm 332$} & \multicolumn{2}{|c|}{$407 \pm 191$} & NS \\
\hline HIV viral load - copies $/ \mathrm{mm}^{3}$ (mean $\left.\pm \mathrm{SD}\right)$ & \multicolumn{2}{|c|}{$13.451 \pm 28.452$} & \multicolumn{2}{|c|}{$14.016 \pm 17.808$} & \multicolumn{2}{|c|}{$12.847 \pm 31.556$} & NS \\
\hline CD4 count $>200$ cells $/ \mathrm{mm}^{3}$ & 42 & 84.0 & 11 & 85.0 & 31 & 84.0 & NS \\
\hline HIV viral load $<400 /$ copies & 24 & 48.0 & 5 & 38.0 & 19 & 51.0 & NS \\
\hline HCV genotype* non-1 & $28 / 43$ & 65.0 & 10 & 77.0 & 18 & 48.0 & 0.11 \\
\hline
\end{tabular}

ALT: alanine aminotransferase; CD4: cluster of differentation; SD: standard deviation; HIV: human immunodeficiency virus; HCV: hepatitis C virus; ${ }^{*} n=43$; NS: not significant. normal ALT if they had at least 3 normal determinations (lower than the upper limit of normal) in the previous 6 months prior to liver biopsy were included in Group 1 (G1). Patients with altered aminotransferases levels were included in Group 2 (G2). All patients were submitted to liver biopsy independent of ALT levels. Using METAVIR classification, a single experienced pathologist performed istological evaluation. The fibrosis progression rate (FPR) was the ratio between the fibrosis stage and HCV infection units/year). To calculate the time required until the development of cirrhosis was divided 4 (F4 = cirrhosis) by the fibrosis progression rate in fibrosis units/year. Advanced liver fibrosis and intense inflammatory activity was considered when they are $\geq 2$.

\section{Statistical analyses}

Quantitative variables were expressed as average \pm standard deviation (SD) and were compared using the Student's $t$-test. Percentages were compared using $\chi^{2}$ test and Fisher's exact test when appropriate. A difference was considered significant if the P-value was less than 0.05. The Statistical Package for the Social Sciences (SPSS) software package version 10 (SPSS Inc., Chicago, IL) was used.

\section{Ethical considerations}

The study was approved by the Research Ethics Committee of the São Paulo Hospital of the Federal University of São Paulo.

\section{RESULTS}

Seventy-nine patients with positive antibody anti-HCV and $\mathrm{HCV}$ infection with known duration were selected. Three of these were excluded by presenting the HBsAg, four due to the absence of HCV-RNA, and 22 patients for loss of the pursuing or refusing the liver biopsy. Then, 50 patients were included. The average age at liver biopsy was $38 \pm 6.6$ years and $40(80 \%)$ were males. The use of intravenous drugs was considered the virus acquisition mode in 43 (86\%) patients. All patients were treated with antiretroviral therapy and $82 \%$ of them used HAART (Table 1). The cluster of differentiation (CD4) cell count was above 200 cells $/ \mathrm{mm}^{3}$ in $84 \%$ of patients and the HIV viral load was less than 400 copies $/ \mathrm{mm}^{3}$ in $48 \%$ of the sample (Table 2). The ALT levels were considered normal in $13(26 \%)$ patients. Advanced liver fibrosis (fibrosis stage $\geq 2$ ) and inflammatory activity $\geq 2$ were identified in $36 \%$ and $54 \%$ of the sample, respectively (Table 3 ).

Regarding ALT levels, both of groups showed similar demographic characteristics and alcohol consumption (Table 1). In addition, the immunological parameters related to HIV infection and genotype distribution were not different between two groups (Table 2).

With respect to histological findings, the HCV-HIV co-infected patients with normal ALT levels had an average of the liver fibrosis stages $(0.77 \pm 0.44$ versus $1.86 \pm 1.38$; 
$\mathrm{p}<0.001)$ and periportal inflammatory activity ( $0.62 \pm 0.77$ versus $2.24 \pm 1.35$; $\mathrm{p}<0.001)$ significantly lower when compared to HCV-HIV coinfected patients with altered aminotransferases levels. None of the patients with normal ALT levels had advanced liver fibrosis stages. Only two (15\%) patients of group 1 had severe inflammatory activity. Furthermore, HCV-HIV co-infected patients with normal aminotransferases levels showed significantly lower liver fibrosis progression rates $(0.058 \pm 0.043$ fibrosis unit $(\mathrm{FU}) /$ year versus $0.118 \pm 0.102$ $\mathrm{FU} /$ year) when compared to patients from group 2 (Table 3 ). The interval between $\mathrm{HCV}$ infection and development of liver cirrhosis (F4), assuming that the fibrosis progression rate is linear, it was 69 (F4/0.058) and 34 years (F4/0.118) for groups 1 e 2, respectively (Figure 1).

\section{DISCUSSION}

In healthy patients the normal range for serum ALT level was set in the 1955 by Karmen ${ }^{32}$ and has changed little since then. Current upper limit of normality (ULN) were set, on average, from 30 to $50 \mathrm{U} / \mathrm{L}$. This was recently challenged by a research group, who claimed that the true normal values are significantly lower. Prati et al suggested that the updated upper limit of normality of alanine aminotransferase should be 30U/L for males and 19U/L for females in subjects with the lowest risk for liver disease ${ }^{33}$.

In chronic hepatitis $C$ patients the definition of persistently normal ALT activity (PNALT) no has consensus. Guidelines from the American Association for the Study of Liver Disease suggest that at least two ALT measurements within the normal range taken over at least 6 months can define those with PNALT ${ }^{34}$. Fonquernie et al. considered PNALT coinfected patients with normal ALT levels documented by repeated testing (at least three values per year) over a 3 -year period ${ }^{29}$.A French study by Bani-Sadr et al, coinfected patients with persistently normal ALT levels were defined as those having three consecutive persistently normal ALT levels over a 6-month period $^{30}$ the same criteria adopted in this study.

Although chronic HCV infection is associated with elevation of ALT activity in most patients, approximately $25 \%$ presented serum ALT activity that is persistently within the normal range ${ }^{35}$. Fonquernie et al. reported among $155 \mathrm{HCV}-\mathrm{HIV}$ coinfected patients, $39(28.5 \%)$ had persistently normal ALT levels ${ }^{29}$. In study involving 381 HCV-HIV coinfected patients, Bani-Sadr et al. identified 36 (9.4\%) subjects with persistently normal ALT values ${ }^{30}$. SanchezConde et al. reported 24/256 (9.4\%) HIV-HCV coinfected patients with persistently normal ALT levels ${ }^{31}$. In the present study, we found 13/50 (26\%) coinfected patients on HAART with persistently normal aminotransferases levels. The variable criteria of PNALT used among several studies may explain the different prevalence rates observed.

In chronic hepatitis $\mathrm{C}$, comparisons between normal and elevated ALT patients have not identified clear differences that could be used as ALT level predictive factors. In this study, there was a tendency to genotype non-1 in patients with altered aminotransferases levels ( $9 \%$ versus $44 \% ; \mathrm{p}=0.06$ ). In the Sanchez-Conde study, patients infected with $\mathrm{HCV}$ genotype 3 were significantly more common

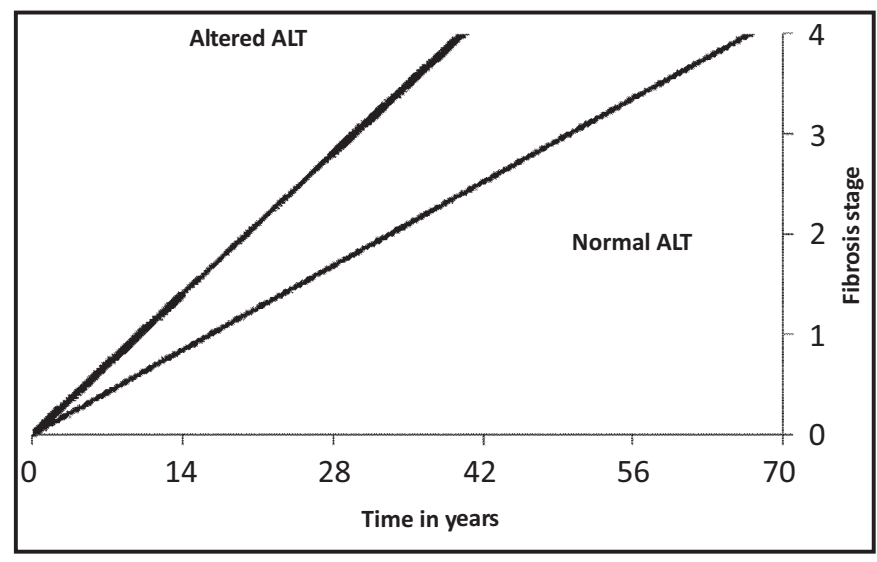

FIGURE 1 - Estimated time to the development of liver cirrhosis according to the ALT levels $(\mathbf{n}=50)$.

ALT: alanine aminotransferase.

between patients with altered ALT levels than in patients with persistently normal ALT levels ${ }^{31}$. In the Bani-Sadr study, a lower mean METAVIR inflammation score, the absence of steatosis and HCV genotype 4 were associated with persistently normal ALT levels ${ }^{30}$. In the Fonquernie study, three factors associated with persistently normal ALT levels were identified, namely: HBsAg negativity, HCV genotype 4 and female sex ${ }^{29}$.

The natural history of chronic hepatitis $C$ is variable. Since most patients with HCV-related chronic hepatitis do not develop cirrhosis, it is logical to infer that host-related and virus-related factors must play a role in the progression to cirrhosis. Liver disease progression takes place over several decades, and is accelerated in the presence of cofactors such as alcohol consumption, insulin resistance, steatosis, older age of acquisition and HIV coinfection. Definition of histological features and liver disease progression in individuals with HCV and normal ALT is complicated because the absence of a gold standard definition for PNALT. Nevertheless, it is generally accepted that individuals with PNALT have milder liver histology when compared to patients with elevated aminotransferases level ${ }^{36,37}$.

Most studies have shown that in HCV-HIV coinfected patients liver fibrosis progression is faster than in $\mathrm{HCV}$ monoinfected patients $^{16-20}$. There are few studies that analyze liver histology in HIV-HCV coinfected patients with PNALT. In this study, individuals with normal aminotransferase levels showed mild histological lesions and slower liver fibrosis progression. In the Bani-Sadr study, none of the 36 patients with PNALT had cirrhosis ${ }^{30}$. In coinfected patients with normal aminotransferases levels Fonquernie et al demonstrated a significantly lower fibrosis score and fibrosis progression rate ${ }^{29}$. In this study, factors known to be related to the progression of chronic hepatitis $\mathrm{C}$ in monoinfected patients such gender, alcohol consumption and age at time of infection were similar in both groups. 
The variables related to cirrhosis development in coinfected patients in according with Benhamou study were similar too ${ }^{17}$. The slower progression of liver fibrosis in coinfected patients with persistently normal ALT levels could be related, in part, to a lower frequency of steatosis in according to the Bani-Sadr study ${ }^{30}$. In the present study, this histological feature was not analyzed. In this study only two patients (15\%) in PNALT group showed significant inflammatory activity which may in part at least explain the slower liver fibrosis progression rate in these patients. Potential limitations that could affect this study's results is that the number of PNALT patients was not high and the absence of a uniform definition for PNALT makes comparisons across different studies difficult.

In conclusion, this study could demonstrate that HCV-HIV coinfected patients with persistently normal aminotransferases exposed to antiretroviral therapy would show mild histological lesions. In these patients liver cirrhosis development is improbable.

\section{CONFLICT OF INTEREST}

The authors declare that there is no conflict of interest.

\section{REFERENCES}

1. Greub G, Ledergerber B, Battegay M, Grob P, Perrin L, Furrer H, et al. Clinical progression, survival, and immune recovery during antiretroviral therapy in patients with HIV-1 and hepatitis C virus coinfection: the Swiss HIV Cohort Study. Lancet 2000; 356:1800-1805.

2. Sulkowski MS, Moore RD, Mehta SH, Chaisson RE, Thomas DL. Hepatitis C and progression of HIV disease. JAMA 2002; 288:199-206.

3. Brau N, Bini EJ, Shahidi A, Aytaman A, Xiao P, Stancic S, et al. Prevalence of hepatitis $\mathrm{C}$ and coinfection with HIV among United States veterans in the New York City metropolitan area. Am J Gastroenterol 2002; 97:2071-2078.

4. Sherman KE, Rouster SD, Chung RT, Rajicic N. Hepatitis C Virus prevalence among patients infected with human immunodeficiency virus: a cross-sectional analysis of the US adult AIDS Clinical Trials Group. Clin Infect Dis 2002; 34:831-837.

5. Quaranta JF, Delaney SR, Alleman S, Cassuto JP, Dellamonica P, Allain JP. Prevalence of antibody to hepatitis $\mathrm{C}$ virus (HCV) in HIV-1-infected patients. J Med Virol 1994; 42:29-32.

6. Staples Jr CT, Rimland D, Dudas D. Hepatitis C in the HIV (human immunodeficiency virus) Atlanta V.A. (Veterans Affairs Medical Center) Cohort Study (HAVACS): the effect of coinfection on survival. Clin Infect Dis 1999; 29:150-154.

7. Ockenga J, Tillmann HL, Trautwein C, Stoll M, Manns MP, Schmidt RE. Hepatitis $\mathrm{B}$ and $\mathrm{C}$ in HIV-infected patients. Prevalence and prognostic value. J Hepatol 1997; 27:18-24.

8. Saillour F, Dabis F, Dupon M, Lacoste D, Trimoulet P, Rispal P, et al. Prevalence and determinants of antibodies to hepatitis $C$ virus and markers for hepatitis $B$ virus infection in patients with HIV infection in Aquitaine. BMJ 1996; 313:461-464.

9. Mendel I, Clotteau L, Lambert S, Buffet-Janvresse C. Hepatitis C virus infection in HIV-positive population in Normandy: antibodies, HCV RNA and genotype prevalence. J Med Virol 1995; 47:231-236.

10. Palella Jr FJ, Delaney KM, Moorman AC, Loveless MO, Fuhrer J, Satten GA, et al. Declining morbidity and mortality among patients with advanced human immunodeficiency virus infection. N Engl J Med 1998; 338:853-860.

11. Bica I, McGovern B, Dhar R, Stone D, McGowan K, Scheib R, et al. Increasing mortality due to end-stage liver disease in patients with human immunodeficiency virus infection. Clin Infect Dis 2001; 32:492-497.

12. Cacoub P, Geffray L, RosenthalE, Perronne C, Veyssier P, Raguin G. Mortality among human immunodeficiency virus-infected patients with cirrhosis or hepatocellular carcinoma due to hepatitis C virus in French Departments of Internal Medicine/ Infectious Diseases, in 1995 and 1997. Clin Infect Dis 2001; 32:1207-1214.

13. Rosenthal E, Poiree M, Pradier C, Perronne C, Salmon-Ceron D, Geffray L, et al. Mortality due to hepatitis C-related liver disease in HIV-infected patients in France (Mortavic 2001 study). AIDS 2003; 17:1803-1809.

14. Mocroft A, Vella S, Benfield TL, Chiesi A, Miller V, Gargalianos P, et al. Changing patterns of mortality across Europe in patients infected with HIV-1. EuroSIDA Study Group. Lancet 1998; 352:1725-1730.
15. Mocroft A, Ledergerber B, Katlama C, Kirk O, Reiss P, d'Arminio Monforte A, et al. Decline in the AIDS and death rates in the EuroSIDA study: an observational study. Lancet 2003; 362:22-29.

16. Sanchez-Quijano A, Andreu J, Gavilan F, Luque F, Abad MA, Soto B, et al. Influence of human immunodeficiency virus type 1 infection on the natural course of chronic parenterally acquired hepatitis C. Eur J Clin Microbiol Infect Dis 1995; 14:949-953.

17. Benhamou Y, Bochet M, Di Martino V, Charlotte F, Azria F, Coutellier A, et al Liver fibrosis progression in human immunodeficiency virus and hepatitis $\mathrm{C}$ virus coinfected patients. The Multivirc Group: Hepatology 1999; 30:1054-1058.

18. Soto B, Sanchez-Quijano A, Rodrigo L, del Olmo JA, Garcia-Bengoechea M, Hernandez-Quero J, et al. Human immunodeficiency virus infection modifies the natural history of chronic parenterally-acquired hepatitis $\mathrm{C}$ with an unusually rapid progression to cirrhosis. J Hepatol 1997; 26:1-5.

19. Mohsen AH, Easterbrook PJ, Taylor C, Portmann B, Kulasegaram R, Murad S, et al Impact of human immunodeficiency virus (HIV) infection on the progression of liver fibrosis in hepatitis C virus infected patients. Gut 2003; 52:1035-1040.

20. Martin-Carbonero L, Benhamou Y, Puoti M, Berenguer J, Mallolas J, Quereda C, et al. Incidence and predictors of severe liver fibrosis in human immunodeficiency virus-infected patients with chronic hepatitis C: a European collaborative study. Clin Infect Dis 2004; 38:128-133.

21. Benhamou Y, Di Martino V, Bochet M, Colombet G, Thibault V, Liou A, et al Factors affecting liver fibrosis in human immunodeficiency virus-and hepatitis $\mathrm{C}$ virus-coinfected patients: impact of protease inhibitor therapy. Hepatology 2001; 34: 283-287.

22. Macias J, Castellano V, Merchante N, Palacios RB, Mira JA, Saez C, et al. Effect of antiretroviral drugs on liver fibrosis in HIV-infected patients with chronic hepatitis C: harmful impact of nevirapine. AIDS 2004; 18 :767-774.

23. Qurish N, Kreuzberg C, Luchters G, Effenberger W, Kupfer B, Sauerbruch T, et al. Effect of antiretroviral therapy on liver-related mortality in patients with HIV and hepatitis C virus coinfection. Lancet 2003; 362:1708-1713.

24. Zylberberg H, Pialoux G, Carnot F, Landau A, Brechot C, Pol S. Rapidly evolving hepatitis $\mathrm{C}$ virus-related cirrhosis in a human immunodeficiency virus-infected patient receiving triple antiretroviral therapy. Clin Infect Dis 1998; 27:1255-1258.

25. Antonello VS, Tovo CV, Kliemann DA, Santos BR, Zaltron VF. Evaluation of APRI score in liver disease following the introduction of antiretroviral therapy in HIV and HCV coinfected versus HIV monoinfected patients. Rev Soc Bras Med Trop 2010; 43:678-681.

26. Alberti A, Noventa F, Benvegnu L, Boccato S, Gatta A. Prevalence of liver disease in a population of asymptomatic persons with hepatitis $\mathrm{C}$ virus infection. Ann Intern Med 2002; 137:961-964.

27. Pradat P, Alberti A, Poynard T, Esteban JI, Weiland O, Marcellin P, et al. Predictive value of ALT levels for histologic findings in chronic hepatitis C: a European collaborative study. Hepatology 2002; 36:973-977.

28. Alberti A, Benvegnu L, Boccato S, Ferrari A, Sebastiani G. Natural history of initially mild chronic hepatitis C. Dig Liver Dis 2004; 36:646-654.

29. Fonquernie L, Serfaty L, Charrois A, Wendum D, Lefebvre B, Girard PM, et al Significance of hepatitis $\mathrm{C}$ virus coinfection with persistently normal alanine aminotransferase levels in HIV-1-infected patients. HIV Med 2004; 5:385-390.

30. Bani-Sadr F, Barange K, Daoud F, Jacomet C, Bicart-See A, Rosenthal E, et al Persistently normal alanine aminotransferase levels in HIV/HCV-coinfected patients: the role of steatosis. HIV Med 2009; 10:417-421.

31. Sanchez-Conde M, Berenguer J, Miralles P, Alvarez F, Carlos Lopez J, Cosin J, et al. Liver biopsy findings for HIV-infected patients with chronic hepatitis $\mathrm{C}$ and persistently normal levels of alanine aminotransferase. Clin Infect Dis 2006; 43:640-644.

32. Karmen A, Wroblewski F, Ladue JS. Transaminase activity in human blood. J Clin Invest 1955; 34:126-131.

33. Prati D, Taioli E, Zanella A, Della Torre E, Butelli S, Del Vecchio E, et al Updated definitions of healthy ranges for serum alanine aminotransferase levels. Ann Intern Med 2002; 137:1-10.

34. Strader DB, Wright T, Thomas DL, Seeff LB. Diagnosis, management, and treatment of hepatitis C. Hepatology 2004; 39:1147-1171.

35. Zeuzem S, Alberti A, Rosenberg W, Marcellin P, Diago M, Negro F, et al. Review article: management of patients with chronic hepatitis C virus infection and "normal" alanine aminotransferase activity. Aliment Pharmacol Ther 2006; 24:1133-1149.

36. Shiffman ML, Diago M, Tran A, Pockros P, Reindollar R, Prati D, et al. Chronic hepatitis $\mathrm{C}$ in patients with persistently normal alanine transaminase levels. Clin Gastroenterol Hepatol 2006; 4:645-652.

37. Persico M, Perrotta S, Persico E, Terracciano L, Folgori A, Ruggeri L, et al Hepatitis C virus carriers with persistently normal ALT levels: biological peculiarities and update of the natural history of liver disease at 10 years. J Viral Hepat 2006; 13:290-296. 